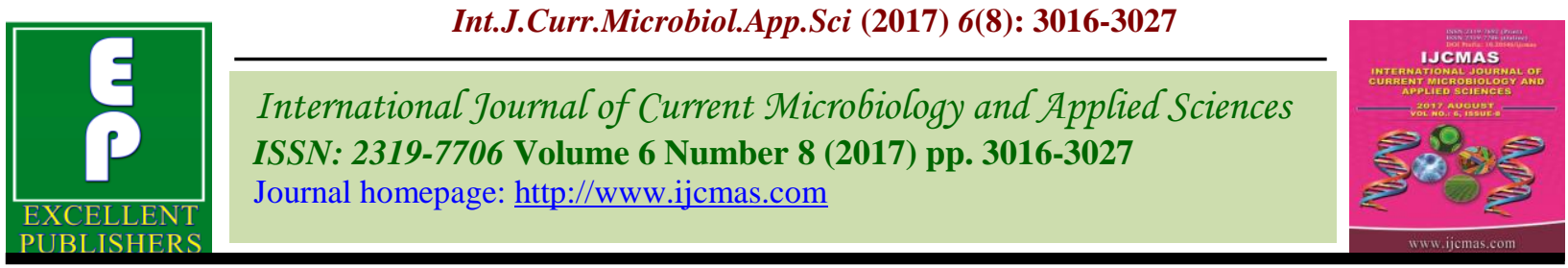

Original Research Article

https://doi.org/10.20546/ijcmas.2017.608.361

\title{
Genetic Diversity Assessment for Growth and Yield Traits in Cauliflower
}

\author{
Diksha Manaware*, A.K. Naidu and Narayan Lal \\ Department of Horticulture, JNKVV, Jabalpur, MP, India \\ *Corresponding author
}

\section{A B S T R A C T}

An investigation entitled "Genetic diversity assessment for growth and yield traits in Cauliflower (Brassica oleracea var. botrytisL.)" was conducted at Horticulture Complex, Department of Horticulture, College of Agriculture JNKVV, Jabalpur (M.P.) during the year 2015-16. The mean performance of the genotypes revealed a wide range of variability for all the traits. The variation was highest for total plant weight (572.27-1220.87), curd weight (238.58-508.83), net curd weight (169.80-392.97), marketable curd yield (76.86169.13), curd yield per hectare (79.21-172.45), curd circumference (9.17-40.40), days to $50 \%$ curd formation (25.00-47.33), days to harvest (40.67-59.33) and curd length (3.4014.88). The phenotypic coefficient of variation were observed to be higher than the corresponding genotypic coefficient of variation for all the characters studied, however the

\section{Keywords}

Genetic

variability,

Correlation

analysis,

Heritability, Genetic advances.

Article Info

Accepted:

23 June 2017

Available Online:

10 August 2017 differences was narrow which implied their relative resistance to environmental variation. The phenotypic coefficient of variations was highest for characters viz., curd length, curd circumference, core length, curd width, net curd weight, curd yield per hectare, marketable curd yield, curd yield per plot, total plant weight and curd weight. However, low PCV was exhibited by traits viz., for stalk length at 45 DAT, days to harvest, stalk length at 30 DAT and days to $50 \%$ curd formation. High genotypic coefficient of variation was noted for curd length, curd circumference, core length, curd width, net curd weight, curd yield per hectare, marketable curd yield, curd yield per plot, curd weight and total plant weight. While it was observed low in the characters i.e. stalk length at 45 DAT, stalk length at 30 DAT, days to harvest, number of leaves per plant at 15 DAT. The value of heritability (broad sense) was recorded very high for curd length, days to harvest, days to curd initiation, curd circumference, days to $50 \%$ curd formation, number of leaves per plant at 45 DAT, curd yield per hectare, marketable curd yield, curd yield per plot. Core length, curd weight, total plant weight, number of leaves per plant at $30 \mathrm{DAT}$, curd width and net curd weight. Genetic advance as percentage of mean ranged between $13.84 \%$ for stalk length at 45 DAT to $103.65 \%$ for curd length. The highest estimate of genetic advance as percentage of mean was recorded for curd length, curd circumference, core length, curd width, curd yield per hectare, curd yield per plot, marketable curd yield, net curd weight, curd weight and total plant weight. Stalk length at 45 DAT showed significant and negative correlation with days to curd initiation, days to $50 \%$ curd formation and number of leaves per plant at 45 DAT. Number of leaves per plant at 45 DAT showed significant and positive correlation with curd circumference, curd width, days to curd initiation, total plant weight, curd weight, curd length, days to $50 \%$ curd formation, core length and days to harvest. Net curd weight showed significant and positive correlation with curd weight.

\section{Introduction}

Cauliflower (Brassica oleracea var. botrytis L.) commonly known as "phoolgobhi" is the most popular vegetable introduced in India in 1822 by Dr. Jemson, who was the In-charge 
of Botanical Garden, Saharanpur, Uttar Pradesh (Nath et al., 1994). The original introduction were Cornish type which originated in England, followed by temperate types, originated in Germany and Netherland in $18^{\text {th }}$ Century (Swarup and Chatterjee, 1972). It is grown in all parts of the country from $11^{\circ} \mathrm{N}$ to $35^{\circ} \mathrm{N}$ latitude (Nath et al., 1994). India is the second largest producer of cauliflower in the world. Area under cauliflower in India is 433.9 thousand hectare with production of 8573.3 thousand metric tonnes and productivity is 19.8 tonnes/ha. Cauliflower occupies $4.12 \%$ area out of a total land under vegetable. It is grown in 25.1 thousand hectare area in Madhya Pradesh with a total annual production of 703.8 thousand metric tonnes and with productivity 28.1 metric tonnes/hectare (National Horticulture Board, 2014). The important cauliflower growing states are West Bengal, Bihar, Haryana, Gujarat, Assam, Uttar Pradesh, Rajasthan, Karnataka and Tamil Nadu. It is also commonly grown in Northern Himalayas, Nilgiri hills, hills of Uttarakhand and J\&K. The edible part of cauliflower botanically known as prefloral fleshy apical meristem or flowering primordial or immature inflorescence and is also called as curd (Sidki, 1962). Cauliflower contains vitamins to the tune of $70 \mathrm{IU}$ vitamin $\mathrm{A}, 50 \mathrm{mg} / 100 \mathrm{~g}$ vitamin $\mathrm{B}$ and $75 \mathrm{mg} / 100 \mathrm{~g}$ vitamin $\mathrm{C}$ and among minerals, 0.73 per cent $\mathrm{Ca}, 0.38$ per cent $\mathrm{P}$, 2.71 per cent $\mathrm{K}, 205 \mathrm{ppm}$ Iron and $15 \mathrm{ppm}$ $\mathrm{Cu}$. Besides vitamins and minerals, cauliflower also contains 2.47 per cent protein, 4.8 per cent total carbohydrate, 0.2 per cent fat and 91.7 per cent water (Brown and Hutchison, 1989).According to Boswell (1949) cauliflower is originated in the Iceland of Cyprus from where it moved to other areas like Syria, Turkey, Egypt, Spain and North Western Europe. In cultivation for a little more than 2500 years back it appeared in about 15 centuries later than cabbage Boswell (1949). According to Allard (1960) cabbage, cauliflower, broccoli, Brussels sprout and other varieties of oleracea have been reported morphologically on the basis of few gene differences. The varieties of $B$. oleracea have same chromosome number ( $\mathrm{n}=9)$. Brassica oleracea is a triple tetrasomic with the genomic formula ABBCCDEEF with 6 basic genomes and showing some secondary pairing (Gerhard, 1960).

Studies on genetic variability with the help of suitable biometrical tools such as coefficient of variability, heritability, and genetic advance become indispensable in breeding programmes for tangible results of desired values. To give a better insight of ancillary characters under selection, correlation and path coefficient analysis are the tools, which are being effectively used for determining the rate of various yield components in different crops, leading to the selection of superior genotypes.

\section{Materials and Methods}

The present investigation on "Genetic diversity assessment for growth and yield traits in Cauliflower" was conducted at Horticulture complex, Department of Horticulture, Jawaharlal Nehru Krishi Vishwa Vidyalaya, Jabalpur (M.P.) during the year 2016-17. The experimental material includes 30 genotypes with two checks of the cauliflower collected from different states of India. The experiment was laid out in Randomized Complete Block Design with three replications and each replication consisted of thirty two genotypes. All the genotypes were randomized separately in each replication.

Estimation of mean, components of variance, phenotypic, genotypic and environmental coefficient of variation, heritability, genetic advance and genetic advance as percentage of mean: 
The mean of different characters were calculated by conventional method:-

Mean $=\frac{\Sigma x_{i}}{n}$

Where,

$\Sigma \mathrm{x}_{\mathrm{i}}=$ The sum of all the observation for ith character.

$\mathrm{n}=$ Number of observations.

Range was recorded by observing the lowest and the highest mean values for each character.

$\sigma_{2} \mathrm{~g}_{\mathrm{i}}=\mathrm{M}_{\mathrm{I}}-\mathrm{E}_{\mathrm{i}}$

$\sigma_{2} \mathrm{e}_{\mathrm{i}}=\mathrm{E}_{\mathrm{i}}$

${ }^{\sigma} \mathrm{p}_{\mathrm{i}}={ }^{\sigma} \mathrm{g}_{\mathrm{i}}+{ }^{\sigma} \mathrm{e}_{\mathrm{i}}$

Where,

${ }^{\sigma_{2}} \mathrm{~g}_{\mathrm{i}}=$ Genotypic variance for $\mathrm{i}^{\text {th }}$ character.

$\sigma_{2} \mathrm{e}_{\mathrm{i}}=$ Environmental variance for $\mathrm{i}^{\text {th }}$ character.

$\sigma_{2} \mathrm{p}_{\mathrm{i}}=$ Phenotypic variance for $\mathrm{i}^{\text {th }}$ character.

Phenotypic and genotypic coefficient of variation (expressed in \%) were calculated by using the formula given by Burton (1952).

Genotypic coefficient of variation (GCV) was calculated as below:

$\mathrm{GCV} \%=\frac{\sqrt{\sigma^{2} g_{i}}}{\bar{X}_{i}} \times 100$

Phenotypic coefficient of variation (PCV)

$P C V \%=\frac{\sqrt{\sigma^{2} p_{i}}}{\overline{X_{i}}} \times 100$
Where,

$\mathrm{X}_{\mathrm{i}}=$ General mean of the $\mathrm{i}^{\text {th }}$ character under consideration.

$\sigma^{2} g_{i}$ and $\sigma^{2} p_{i}=$ Genotypic and phenotypic standard deviation of the $i^{\text {th }}$ character respectively.

\section{Heritability and genetic advance}

Heritability (broad sence) which is ratio of genotypic variance to the total phenotypic variance is symbolized as h2 (BS) and expressed in percentage. Estimation of heritability was done as per the formula given by Hanson et al., (1956).

$$
h^{2}(B S)=\frac{\sigma^{2} g_{i}}{\sigma^{2} p_{i}} \times 100
$$

OR

$$
\begin{gathered}
\text { Genotypic variance of the ith character } \\
\text { Phenotypic variance of the ith character }
\end{gathered}
$$

\section{Genetic advance}

The estimation of genotypic and phenotypic variance and heritability were used to determine the expected genetic advance as suggested by Johnson et al., (1955) and expressed as -

Genetic advance $(\mathrm{GA})=\mathrm{k} \times \sigma^{2} \mathrm{p} \times \mathrm{h}^{2}$

Where,

$\mathrm{k}=$ constant, 2.06 at $5 \%$ selection intensity

$\sigma^{2} \mathrm{p}=$ phenotypic standard deviation

$\mathrm{h}^{2}=$ heritability in broad sense

Genetic advance as a percentage of mean was calculated as per formula given below: 
GA as percentage of mean $=\frac{\text { GA }}{\bar{x}}$

Where,

$\mathrm{GA}=$ Genetic advance

$\overline{\mathrm{X}}=$ mean

\section{Correlation coefficients}

Correlation coefficients were calculated in all possible combinations taking all the characters into consideration at genotypic, phenotypic and environmental levels by using the formula as proposed by Miller et al., (1958).

$$
r=\frac{\sum x y-\frac{\sum x x \Sigma y}{n}}{\sqrt{\left(\sum x^{2}-\frac{(\Sigma x)^{2}}{n}\right)\left(\Sigma y^{2}-\frac{(\Sigma y)^{2}}{n}\right)}}
$$

Where,

$\mathrm{r}=$ Correlation coefficient

$\mathrm{n}=$ Number of treatments

$\mathrm{X}$ and $\mathrm{Y}=$ Character under study

\section{Results and Discussion}

\section{Genetic variability}

The mean performance of the genotypes (Table 2) revealed a wide range of variability for all the traits. The variation was highest for total plant weight (572.27-1220.87), curd weight (238.58-508.83), net curd weight (169.80-392.97), marketable curd yield (76.86-169.13), curd yield per hectare (79.21172.45), curd circumference (9.17-40.40), days to $50 \%$ curd formation (25.00-47.33), days to harvest (40.67-59.33) and curd length (3.40-14.88). The findings were similar to as reported by Singh et al., (2006) found the wide range of variability for curd weight and net curd weight, Kumar et al., (2010) reported the highest variation for days to $50 \%$ curd formation and net curd weight, Kumar et al., (2011) found the wide range of variability for days to $50 \%$ curd formation, net curd weight, marketable curd yield. Chittora and Singh (2015) reported highest variation for total plant weight and net curd weight. Kumari et al., (2016) reported highest variation for total plant weight and marketable curd yield.

\section{Coefficient of variation}

In the present findings phenotypic coefficient of variation were observed to be higher than the corresponding genotypic coefficient of variation for all the characters studied, however the differences was narrow which implied their relative resistance to environmental variation. It also described that genetic factors were predominantly responsible for expression of those attributes and selection could be made effectively on the basis of phenotypic performance. The findings of Singh et al., (2006) and Kumar et al., (2011) were similar to that of the present findings.

\section{Phenotypic coefficient of variations}

The phenotypic coefficient of variation ranged from $11.32 \%$ for stalk length at 45 DAT to $51.42 \%$ for curd length. The phenotypic coefficient of variations was highest for characters viz., curd length, curd circumference, core length, curd width, net curd weight, curd yield per hectare, marketable curd yield, curd yield per plot, total plant weight and curd weight. The findings are in close harmony with the result of Thakur and Thakur (2002) and Sharma et al., (2003) for head yield per plot, Singh et al., (2006) for curd length, Singh et al., (2011) for total plant weight, Singh et al., (2013) for curd weight. 
However, low PCV was exhibited by traits viz., for stalk length at 45 DAT, days to harvest, stalk length at 30 DAT and days to $50 \%$ curd formation. The findings of Kumar et al., (2010) and Singh et al., (2011) for days to $50 \%$ curd formation were similar to that of the present findings. Stalk length at 15 DAT, days to curd initiation, number of leaves per plant at 45 DAT, number of leaves at 30 DAT, number of leaves at 15 DAT exhibited moderate phenotypic coefficient of variation. The findings of Singh et al., (2011) for total plant weight and number of non-wrapper leaves, Singh et al., (2013) for days to curd initiation were similar to that of the present findings.

\section{Genotypic coefficient of variation (GCV)}

The genotypic coefficient of variation varied from $8.72 \%$ for stalk length at 45 DAT to $50.84 \%$ for curd length. High genotypic coefficient of variation was noted for curd length, curd circumference, core length, curd width, net curd weight, curd yield per hectare, marketable curd yield, curd yield per plot, curd weight and total plant weight. The findings are in close harmony with Kumar and korla (2001), Sharma et al., (2003), Singh et al., (2013), Kumari et al., (2016) were similar to that of the present findings.

While it was observed low in the characters i.e. stalk length at 45 DAT, stalk length at 30 DAT, days to harvest, number of leaves per plant at 15 DAT. The findings of Meena et al., (2010) for days to harvest, Singh et al., (2011) and Singh et al., (2013) for leaves per plant were similar to that of the present findings which indicated that there is limited scope for improvement. Rest of the characters viz., days to curd initiation, stalk length at 15 DAT, number of leaves per plant at 45 DAT, number of leaves at $30 \mathrm{DAT}$, days to $50 \%$ curd formation, were showed moderate genotypic coefficient of variation. The findings of Singh et al., (2013) for days to curd initiation, Kumari et al., (2016) were similar to that of the present findings.

\section{Heritability (Broad sense)}

The heritability (BS) was computed for each of the characters by the variance components for estimating their relative magnitudes of genotypic and phenotypic variability contributed through environmental factors. The estimates of heritability (BS) for all the characters have been discussed in table 2 . It was partitioned as very high (above 90\%), high (70 to $90 \%)$, medium $(50-70 \%)$ and low (less than $50 \%$ ). The value of heritability (broad sense) was recorded very high for curd length, days to harvest, days to curd initiation, curd circumference, days to $50 \%$ curd formation, number of leaves per plant at 45 DAT, curd yield per hectare, marketable curd yield, curd yield per plot. core length, curd weight, total plant weight, number of leaves per plant at 30 DAT, curd width and net curd weight. The results were in close proximate to that of the Kumar and Korla (2001) for number of non-wrapping leaves per plant, Sharma et al., (2003), Meena et al., (2010) and Meena et al., (2011) for yield and head width, Soni et al., (2013) for days to harvest, core length, head weight and curd yield per hectare. It reflected that the phenotypes were the true representative of their genotype and selection based on phenotypic performance would be reliable. However, it was recorded to be high for stalk length at $15 \mathrm{DAT}$, number of leaves per plant at 15 DAT. Moderate heritability was recorded for stalk length at 30 DAT and stalk length at 45 DAT. The findings of Singh et al., (2006), Soni et al., (2013) for stalk length for 45 DAT were similar to that of the present findings.

\section{Genetic advance (as \% of mean)}

Due to masking influence of environment upon characters concerned, values of genetic advance exhibited high fluctuations. 
Therefore, to attain relative comparison of the characters in relation to environment genetic advance as percentage of mean was calculated to predict the genetic gain. The estimated values of genetic advance as percent of mean were classified as high (more than 45\%), moderate (30-45\%) and low (less than 30\%).

Genetic advance as percentage of mean ranged between $13.84 \%$ for stalk length at 45 DAT to $103.65 \%$ for curd length. The highest estimate of genetic advance as percentage of mean was recorded for curd length, curd circumference, core length, curd width, curd yield per hectare, curd yield per plot, marketable curd yield, net curd weight, curd weight and total plant weight. The findings of Singh et al., (2006) for curd width, Singh et al., (2011) for core length, net curd weight, total plant weight, Singh et al., (2013) for curd weight, curd yield per hectare, marketable curd yield, Soni et al., (2013) for core length, curd yield per hectare, curd weight, Chura et al., (2016) for curd yield per plot, net curd weight were similar to that of the present findings.

Days to curd initiation, number of leaves at 45 DAT, number of leaves at 30 DAT, stalk length at 15 DAT and days to $50 \%$ curd formation showed moderate value of genetic advance as percentage of mean. The findings of Kumar et al., (2010) for days to 50\% curd formation, Singh et al., (2013) for days to curd initiation, Soni et al., (2013) for stalk length, Chittora and Singh (2015) for days to curd initiation, Chura et al., (2016) for number of leaves at 45 DAT and stalk length were similar to that of the present findings. Whereas, low estimates were observed for number of leaves at 15 DAT, days to harvest, stalk length at 30 DAT and stalk length at 45 DAT. The findings of Singh et al., (2011), Singh et al., (2013), Chittora and Singh (2015) for days to harvest and stalk length at 45 DAT were similar to that of the present findings.
High genetic variability coupled with high genetic advance as percentage of mean for traits like curd length, curd circumference, curd width, total plant weight, curd weight, net curd weight, curd yield per plot, marketable curd yield, curd yield per hectare and core length suggested that the preponderance of additive genes. It also indicated higher response for selection to high yields as these characters are governed by additive gene actions. The results were in consonance with Singh et al., (2011).High heritability supplemented with moderate genetic advances as percentage of mean were manifested by days to curd initiation, days to $50 \%$ curd formation, number of leaves per plant at $45 \mathrm{DAT}$ and $30 \mathrm{DAT}$ and stalk length at 15 DAT which might be attributed to additive gene action conditioning their expression and phenotypic selection for their amenability can be brought about.

The results were in consonance with Chittora and Singh (2015).High heritability coupled with low genetic advance as percentage of mean was observed for days to harvest, number of leaves per plant at 15 DAT, stalk length at 30 DAT and 45 DAT. These findings were in agreement with Singh et al., (2011). This revealed the predominance of non-additive gene action in the expression of these characters; hence direct selection would not be effective.

\section{Correlation coefficient analysis}

Correlation coefficient was worked out at phenotypic, genotypic and environmental levels for all possible combination of twelve yield and its attributing characters (Table 3). Correlation coefficient analysis measures the mutual relationship between plant characters and determines the component characters on which selection can be made for genetic improvement of yield. Investigation regarding the presence of component and nature of association among themselves is essential and 
pre-requisite for improvement in yield. The results of phenotypic correlation coefficients have been discussed only as the genotypic and environmental correlation were mostly influenced by the environmental conditions, hence phenotypic correlation will give the correct idea about the association between two variables. The magnitude of genotypic correlation was higher than the phenotypic correlation for all the traits that indicated inherent association between various characters. The findings were in agreement to Rai et al., (2003), Rai and Asati (2004), Meena et al., (2012).

The component of variance was calculated as follows

\begin{tabular}{|l|l|l|l|}
\hline S. No. & Source & M.S.S. & Expected M.S.S. \\
\hline 1. & Replications & - & - \\
\hline 2. & Genotypes & $\mathrm{M} \mathrm{i}$ & $\sigma^{2} \mathrm{ei}+r . \sigma^{2} \mathrm{gi}$ \\
\hline 3. & Error & $\mathrm{E} \mathrm{i}$ & $\sigma^{2} \mathrm{ei}$ \\
\hline
\end{tabular}

Table.1 Details of genotypes and checks used in the study

\begin{tabular}{|l|c|c|c|c|c|c|c|}
\hline $\begin{array}{c}\text { S. } \\
\text { No. }\end{array}$ & Treatment & Symbol & Source & S. No. & Treatment & Symbol & Source \\
\hline 1. & JBOB-1 & T1 & IIVR,VARANASI & 17. & JBOB-17 & T17 & IIVR,VARANASI \\
\hline 2. & JBOB-2 & T2 & IIVR,VARANASI & 18. & JBOB-18 & T18 & IIVR,VARANASI \\
\hline 3. & JBOB-3 & T3 & IIVR,VARANASI & 19. & JBOB-19 & T19 & IIVR,VARANASI \\
\hline 4. & JBOB-4 & T4 & IIVR,VARANASI & 20. & JBOB-20 & T20 & IIVR,VARANASI \\
\hline 5. & JBOB-5 & T5 & IIVR,VARANASI & 21. & JBOB-21 & T21 & IIVR,VARANASI \\
\hline 6. & JBOB-6 & T6 & IIVR,VARANASI & 22. & JBOB-22 & T22 & IIVR,VARANASI \\
\hline 7. & JBOB-7 & T7 & IIVR,VARANASI & 23. & JBOB-23 & T23 & IIVR,VARANASI \\
\hline 8. & JBOB-8 & T8 & IIVR,VARANASI & 24. & JBOB-24 & T24 & IIVR,VARANASI \\
\hline 9. & JBOB-9 & T9 & IIVR,VARANASI & 25. & JBOB-25 & T25 & IIVR,VARANASI \\
\hline 10. & JBOB-10 & T10 & IIVR,VARANASI & 26. & JBOB-26 & T26 & IIVR,VARANASI \\
\hline 11. & JBOB-11 & T11 & IIVR,VARANASI & 27. & JBOB-27 & T27 & IIVR,VARANASI \\
\hline 12. & JBOB-12 & T12 & IIVR,VARANASI & 28. & JBOB-28 & T28 & IIVR,VARANASI \\
\hline 13. & JBOB-13 & T13 & IIVR,VARANASI & 29. & JBOB-29 & T29 & IIVR,VARANASI \\
\hline 14. & JBOB-14 & T14 & IIVR,VARANASI & 30. & JBOB-30 & T30 & IIVR,VARANASI \\
\hline 15. & JBOB-15 & T15 & IIVR,VARANASI & 31. & Pusa sharad (C) & T31 & IIVR,VARANASI \\
\hline 16. & JBOB-16 & T16 & IIVR,VARANASI & 32. & PH-2 (C) & T32 & IIVR,VARANASI \\
\hline
\end{tabular}


Table.2 Estimates of genetic parameters of variations for various characters

\begin{tabular}{|c|c|c|c|c|c|c|c|c|c|}
\hline \multicolumn{2}{|l|}{ Characters } & \multirow{3}{*}{$\begin{array}{l}\text { Grand } \\
\text { Mean } \\
0.81\end{array}$} & \multicolumn{2}{|l|}{ Range } & \multicolumn{2}{|c|}{ Coefficient of variations } & \multirow{3}{*}{$\begin{array}{l}\text { Heritability } \\
\% \text { (BS) } \\
76.91\end{array}$} & \multirow{3}{*}{$\begin{array}{l}\text { Genetic } \\
\text { Advance } \\
0.29\end{array}$} & \multirow{3}{*}{$\begin{array}{l}\text { GA as \% of } \\
\text { mean } \\
35.69\end{array}$} \\
\hline & & & \multirow{2}{*}{$\begin{array}{l}\text { Min. } \\
0.53\end{array}$} & \multirow{2}{*}{$\begin{array}{c}\text { Max. } \\
1.33\end{array}$} & \multirow{2}{*}{$\begin{array}{l}\text { Phenotypic } \\
22.40\end{array}$} & \multirow{2}{*}{$\begin{array}{l}\text { Genotypic } \\
19.64\end{array}$} & & & \\
\hline Stalk length $(\mathrm{cm})$ at & 15 DAT & & & & & & & & \\
\hline & 30 DAT & 1.23 & 0.97 & 1.60 & 12.18 & 10.09 & 68.61 & 0.21 & 17.35 \\
\hline & 45 DAT & 1.38 & 1.10 & 1.77 & 11.32 & 8.72 & 59.25 & 0.19 & 13.84 \\
\hline \multirow[t]{3}{*}{ Number of leaves per plant at } & 15 DAT & 12.08 & 8.27 & 16.33 & 17.44 & 15.15 & 75.49 & 3.28 & 27.12 \\
\hline & 30 DAT & 16.24 & 10.80 & 21.47 & 19.04 & 18.32 & 92.55 & 5.90 & 36.32 \\
\hline & 45 DAT & 17.30 & 11.87 & 22.47 & 19.08 & 18.64 & 95.42 & 6.49 & 37.50 \\
\hline Days to curd initiation & & 27.64 & 19.33 & 37.33 & 20.44 & 20.13 & 97.02 & 11.29 & 40.86 \\
\hline Days to $50 \%$ curd formation & & 37.73 & 25.00 & 47.33 & 15.58 & 15.23 & 95.53 & 11.57 & 30.66 \\
\hline Days to harvest & & 47.18 & 40.67 & 59.33 & 12.09 & 11.95 & 97.72 & 11.48 & 24.33 \\
\hline Curd length (cm) & & 8.20 & 3.40 & 14.88 & 51.42 & 50.84 & 97.76 & 8.50 & 103.65 \\
\hline Curd circumference $(\mathbf{c m})$ & & 24.68 & 9.17 & 40.40 & 41.09 & 40.39 & 96.64 & 20.19 & 81.81 \\
\hline Curd width $(\mathrm{cm})$ & & 10.35 & 5.23 & 16.30 & 28.69 & 27.51 & 91.94 & 5.62 & 54.34 \\
\hline Core length $(\mathrm{cm})$ & & 7.18 & 4.03 & 11.40 & 34.80 & 33.85 & 94.63 & 4.87 & 67.88 \\
\hline Total plant weight (kg) & & 915.35 & 572.27 & 1220.87 & 24.77 & 24.00 & 93.92 & 438.66 & 47.92 \\
\hline Curd weight (g) & & 381.39 & 238.58 & 508.83 & 24.75 & 24.01 & 94.13 & 183.05 & 47.99 \\
\hline Net curd weight (g) & & 280.00 & 169.80 & 392.97 & 26.25 & 24.95 & 90.32 & 136.77 & 48.85 \\
\hline Curd yield per plot (kg) & & 7.63 & 4.752 & 10.345 & 24.95 & 24.35 & 95.25 & 3.74 & 49.01 \\
\hline Marketable curd yield (q/ha) & & 124.17 & 79.21 & 172.45 & 24.95 & 24.35 & 95.25 & 62.34 & 48.96 \\
\hline Curd Yield per hectare (q/ha) & & 127.32 & 76.86 & 169.13 & 24.99 & 24.39 & 95.26 & 60.88 & 49.03 \\
\hline
\end{tabular}


Table.3 Estimates of genotypic and phenotypic correlation coefficients among curd yield and its attributing traits

\begin{tabular}{|c|c|c|c|c|c|c|c|c|c|c|c|c|}
\hline Characters & & $\begin{array}{l}\text { No. of leaves / } \\
\text { plant at } 45 \\
\text { DAT }\end{array}$ & $\begin{array}{l}\text { Days to } \\
\text { curd } \\
\text { initiation }\end{array}$ & $\begin{array}{l}\text { Days to } \\
\mathbf{5 0 \%} \text { curd } \\
\text { formation }\end{array}$ & $\begin{array}{l}\text { Days to } \\
\text { harvest }\end{array}$ & $\begin{array}{l}\text { Curd } \\
\text { length } \\
(\mathrm{cm})\end{array}$ & $\begin{array}{l}\text { Curd } \\
\text { circumference } \\
(\mathrm{cm})\end{array}$ & $\begin{array}{l}\text { Curd } \\
\text { width } \\
\text { (cm) }\end{array}$ & $\begin{array}{l}\text { Core } \\
\text { length } \\
\text { (cm) }\end{array}$ & $\begin{array}{l}\text { Total plant } \\
\text { weight } \\
(\mathrm{kg})\end{array}$ & $\begin{array}{l}\text { Net curd } \\
\text { weight } \\
\text { (g) }\end{array}$ & $\begin{array}{l}\text { Curd } \\
\text { weight } \\
\text { (g) }\end{array}$ \\
\hline \multirow[t]{2}{*}{ Stalk length $(\mathrm{cm}) 45$ DAT } & $\mathrm{G}$ & -0.460 & -0.327 & -0.333 & -0.024 & -0.108 & -0.157 & -0.105 & -0.124 & -0.168 & -0.082 & -0.167 \\
\hline & $\mathrm{P}$ & $-0.349 * *$ & $-0.226^{*}$ & $-0.255^{*}$ & -0.025 & -0.101 & -0.116 & -0.057 & -0.104 & -0.106 & -0.040 & -0.108 \\
\hline \multirow{2}{*}{$\begin{array}{l}\text { No. of leaves / plant at } 45 \\
\text { DAT }\end{array}$} & $\mathrm{G}$ & & 0.705 & 0.655 & 0.484 & 0.688 & 0.795 & 0.733 & 0.639 & 0.708 & 0.042 & 0.708 \\
\hline & $\mathrm{P}$ & & $0.676^{* *}$ & $0.631 * *$ & $0.469 * *$ & $0.666 * *$ & $0.770 * *$ & $0.691 * *$ & $0.613 * *$ & $0.670 * *$ & 0.037 & $0.670 * *$ \\
\hline \multirow[t]{2}{*}{ Days to curd initiation } & $\mathrm{G}$ & & & 0.916 & 0.764 & 0.835 & 0.857 & 0.767 & 0.883 & 0.902 & 0.385 & 0.903 \\
\hline & $\mathrm{P}$ & & & $0.876 * *$ & $0.747 * *$ & $0.814 * *$ & $0.830 * *$ & $0.733 * *$ & $0.847 * *$ & $0.872 * *$ & $0.372 * *$ & $0.872 * *$ \\
\hline \multirow{2}{*}{$\begin{array}{l}\text { Days to } 50 \% \text { curd } \\
\text { formation }\end{array}$} & $\mathrm{G}$ & & & & 0.853 & 0.825 & 0.864 & 0.741 & 0.842 & 0.846 & 0.340 & 0.846 \\
\hline & $\mathrm{P}$ & & & & $0.825 * *$ & $0.795 * *$ & $0.830 * *$ & $0.695 * *$ & $0.797 * *$ & $0.793 * *$ & $0.306 * *$ & $0.794 * *$ \\
\hline \multirow[t]{2}{*}{ Days to harvest } & $\mathrm{G}$ & & & & & 0.743 & 0.814 & 0.692 & 0.722 & 0.757 & 0.239 & 0.757 \\
\hline & $\mathrm{P}$ & & & & & $0.725 * *$ & $0.793 * *$ & $0.664 * *$ & $0.702 * *$ & $0.727 * *$ & $0.226^{*}$ & $0.726^{* *}$ \\
\hline \multirow[t]{2}{*}{ Curd length $(\mathrm{cm})$} & G & & & & & & 0.745 & 0.644 & 0.894 & 0.835 & 0.379 & 0.835 \\
\hline & $\mathrm{P}$ & & & & & & $0.730 * *$ & $0.599 * *$ & $0.858 * *$ & $0.794 * *$ & $0.348 * *$ & $0.795^{* *}$ \\
\hline \multirow[t]{2}{*}{ Curd circumference $(\mathrm{cm})$} & $\mathrm{G}$ & & & & & & & 0.921 & 0.778 & 0.864 & 0.133 & 0.863 \\
\hline & $\mathrm{P}$ & & & & & & & $0.878 * *$ & $0.746^{* *}$ & $0.822 * *$ & 0.123 & $0.822 * *$ \\
\hline \multirow[t]{2}{*}{ Curd width $(\mathrm{cm})$} & $\mathrm{G}$ & & & & & & & & 0.738 & 0.788 & 0.133 & 0.787 \\
\hline & $\mathrm{P}$ & & & & & & & & $0.694 * *$ & $0.746 * *$ & 0.137 & $0.745^{* *}$ \\
\hline \multirow[t]{2}{*}{ Core length $(\mathrm{cm})$} & $\mathrm{G}$ & & & & & & & & & 0.911 & 0.489 & 0.912 \\
\hline & $\mathrm{P}$ & & & & & & & & & $0.866^{* *}$ & $0.459 * *$ & $0.866^{* *}$ \\
\hline \multirow[t]{2}{*}{ Total plant weight $(\mathrm{kg})$} & $\mathrm{G}$ & & & & & & & & & & 0.410 & 0.978 \\
\hline & $\mathrm{P}$ & & & & & & & & & & $0.454 * *$ & $0.999 * *$ \\
\hline \multirow[t]{2}{*}{ Net curd weight (g) } & $\mathrm{G}$ & & & & & & & & & & & 0.411 \\
\hline & $\mathrm{P}$ & & & & & & & & & & & $0.454 * *$ \\
\hline
\end{tabular}

Significant at $5 \%$ level $=*$; Significant at $1 \%$ level $=* *$ 


\section{Stalk length at 45 DAT}

Stalk length at 45 DAT showed significant and negative correlation with days to curd initiation, days to $50 \%$ curd formation and number of leaves per plant at 45 DAT. These results are in agreement with the finding of Rai et al., (2003).

\section{Number of leaves per plant at 45 DAT}

Number of leaves per plant at 45 DAT showed significant and positive correlation with curd circumference, curd width, days to curd initiation, total plant weight, curd weight, curd length, days to $50 \%$ curd formation, core length and days to harvest. These results are in agreement with the finding of Rai et al., (2003).

\section{Days to curd initiation}

Days to curd initiation expressed significant and positive correlation with days to $50 \%$ curd formation, total plant weight, curd weight, core length, curd circumference, curd length, days to harvest, curd width and net curd weight.

\section{Days to $50 \%$ curd formation}

Days to $50 \%$ curd formation expressed significant and positive correlation with curd circumference, days to harvest, core length, curd length, curd weight, total plant weight, curd width and net curd weight. These results are in close harmony with the finding of Sheemar et al., (2012) for curd circumference and net curd weight.

\section{Days to harvest}

Days to harvest showed significant and positive correlation with curd circumference, total plant weight, curd weight, curd length, core length, curd width and net curd weight.

\section{Curd length}

Association of Curd length was exhibited significant and positive with core length, curd weight, total plant weight, curd circumference, curd width and net curd weight.

These findings corroborated the earlier findings of Antonova (2009), Adzic et al., (2012) for head weight.

\section{Curd circumference}

The correlation coefficient of curd circumference was found to be positive and significant with curd width, total plant weight, curd weight and core length.

These results are in agreement with the findings of Antonova (2009) for head weight, Kibar et al., (2014).

\section{Curd width}

Curd width showed significant and positive correlation with total plant weight, curd weight and core length.

These results are in close harmony with the findings of Antonova (2009), Adzic et al., (2012) for head weight, Kibar et al., (2014) for total plant weight and curd weight.

\section{Core length}

Correlation coefficient of core length was found to be positive and significant with total plant weight, curd weight and net curd weight.

\section{Total plant weight}

Total plant weight expressed significant and positive correlation with curd weight and net curd weight. The results corroborated the 
findings of Rai and Asati (2004), Meena et al., (2010) for curd weight and net curd weight.

\section{Net curd weight}

Net curd weight showed significant and positive correlation with curd weight. These results are in similar with the findings of Kumar et al., (2005), Singh et al., (2006), Singh et al., (2013) for curd weight.

\section{References}

Adzic, S., Pavlovic, S., Jokanovic, M.B., Cvikic, D., Pavlovic, N., Zdravkovic, J. and Prodanovic, S. 2012. Correlation of important agronomic characteristics and yield of medium late genotypes of head cabbage. Acta Horticulturae, 960: 159164.

Allard, R.W., 1960. Principles of Plant Breeding. John Wiley and Sons Inc. New York $185 \mathrm{p}$.

Anonymous. 2014. National Horticulture Board, Gurgaon-122 015 Haryana, India

Antonova, G., 2009. Study on variation, heritability and correlation in open pollinated cultivars and new breeding lines of late head cabbage. Acta Horticulturae, 830: 143-150.

Boswell, V.R., 1949. Our vegetable travellers. National geographic magazine96: 170177.

Brown, H.D., and Hutchison, C.S. 1989. Studies on factors involved in curd and flower formation in cauliflower (Brassica oleracea var. botrytis L.). Vegetable Science. J. B. Lippincot. Company. New York pp. 21-30.

Burton, G.W., 1952. Quantitative inheritance in grasses. Proceedings of the 6th International Grassland Congress 1: 227285.

Chittora, A., and Singh, D.K. 2015. Genetic variability studies in early cauliflower (Brassica oleracea var. botrytis L.). Electronic Journal of Plant Breeding,
6(3): 842-847.

Chura, A., Negi, P.S. and Pandey, V. 2016. Assessment of heritability and genetic advancement for yield and yield attributing traits (Brassicaoleracea var. Capitata L.). International Journal of Agriculture Innovations and Research, 5(1): 2319-1473.

Gerhard, R., 1960. Beitrage zur analyse des Brassica genoms. Chromosoma 11: 205

Hanson, C.H., Robinson, H.F. and Comstock, R.E. 1956. Bimetrical studies of yield in segregating population of Korean Lespedsa. Agronomy Journal, 48: 268272.

Johnson, H.W., Robinson, H.F. and Comstock, R.E. 1955. Estimates of genetics and environment variability in soybean. Agriculture Journal, 47: 314-318.

Kibar, B., Karaağaç, O. and Kar, H. 2014. Correlation and path coefficient analysis of yield and yield components in cabbage (Brassica Oleracea Var. Capitata L.). Acta Scientiarum Polonorum Hortorum Cultus, 13(6): 87-97.

Kumar, D., Kohli, U.K., Kanwar, H.S. and Mehta, S. 2005. Correlation and path analysis in snowball type cauliflower (Brassca oleracca var. botrytis L.). Indian Journal of Horticulture, 62(4): 409-410.

Kumar, M., Sharma, S.R., Kalia, P. and Saha, P. 2010. Genetic variability and character association for quantitative and quality traits in early maturing Indian cauliflowers. Indian Journal of Horticulture, 67: 218-223.

Kumar, M., Sharma, S.R., Kalia, P. and Saha, P. 2011. Genetic variability and character association for yield and quality traits in early maturing Indian cauliflowers. Indian Journal of Horticulture, 68(2), June 2011: 206-211

Kumar, S., and Korla, B.N. 2001. Genetic variability, heritability and genetic advance for yield and its contributing traits in late cauliflower (Brassica oleracea var. botrytis L.). Himachal Journal of Agricultural Research, 27 (1/2): 114-116. 
Kumari, S., Katoch, V., Sharma, A. and Kumar, V. 2016. Variability studies in sprouting broccoli hybrids (brassica oleracea l. var. italica plenck) under mid hills of northwestren Himalayas. The Bioscan, 11(1): 569-572.

Meena, M.L., Ram, R.B. and Lata, R. 2010. Studies on variability, correlation and path analysis for morphological and horticultural traits in cabbage (Brassica oleracea var. capitata L.) genotypes under Lucknow conditions. Horticultural Journal, 23 (2): 73-77.

Meena, M.L., Ram, R.B., Lata, R. and Sharma, S.R. 2012. Estimates of genetic variability and correlation studies for some quality traits in cabbage (Brassica oleracea var. capitata). Indian Journal of Agricultural Sciences, 82 (4): 370-372.

Miller, P.A., Williams, J.C. and Comstock, R.E. 1958. Estimate of genotypic and environmental variances and covariances in upland cotton and their implication in selection. Agronomy Journal, 50: 126131.

Nath, P., Velayudhan, S. and Singh, D.P. 1994. Vegetables for the tropical region. ICAR, New Delhi, India 147-163.

Rai, N., and Asati, B.S. 2004. Correlation and path coefficient analysis for the yield and its traits in cabbage. Orissa Journal of Horticulture, 32 (1): 48-51.

Rai, N., Singh, A.K. and Yadav, R.K. 2003. Correlation and path coefficient analysis for the yield and its traits in cabbage. Indian Journal of HillFarming, 16 (1/2): 61-65.

Sharma, D., Kohli, U.K. and Kanwar, H.S. 2003. Variability studies in cabbage (Brassica oleracea var. capitata
L.).Haryana Journal of Horticultural Sciences, 32 (1/2): 143-144.

Sheemar, G., Singh, D., Malik, A. and Kumar, A. 2012. Correlation and path analysis studies of economic traits in cauliflower (Brassica oleracea var botrytis L.). Journal of Agricultural Technology, 8(5): 1791-1799.

Sidki, S., 1962. Variability studies in cauliflower for economic character. American Journal of Botany, 49: 290297.

Singh, B., Pandey, A.K., Verma, A. and Rai, M. 2006. Genetic Variability in Aghani Group of Indian Cauliflower (Brassica oleracea var. botrytis). Indian Journal of Plant Genetic Resources, 19(1): 113-117.

Singh, B.K., Sharma, S.R., Kalia, P. and Singh, B. 2011. Genetic variability for antioxidants and horticultural traits in cabbage. Indian Journal of Horticulture, 68 (1): 51-55

Singh, P., Kumar, S., Maji, S. and Singh, A. 2013. Genetic variability, heritability and genetic advance in cauliflower (Brassica oleracea var. botrytis L.). International Journal of Plant Sciences, 8: 179-182.

Soni, S., Kumar, S., Maji, S. and Kumar, A. 2013. Heritability and genetic advance in cabbage (brassica oleracea var. capitata L.) under Lucknow condition. HortFlora Research Spectrum, 2(3): 274-276.

Swarup, V., and Chatterjee, S.S. 1972. Origin and genetic improvement of Indian cauliflower. Economic Botany, 26: 381393.

Thakur, M.C., and Thakur, A.K. 2002. Genetic variability studies in cabbage. Horticultural Journal, 15 (3): 71-76.

\section{How to cite this article:}

Diksha Manaware, A.K. Naidu and Narayan Lal. 2017. Genetic Diversity Assessment for Growth and Yield Traits in Cauliflower. Int.J.Curr.Microbiol.App.Sci. 6(8): 3016-3027. doi: https://doi.org/10.20546/ijcmas.2017.608.361 